\author{
MARCIN PODLEŚ \\ ORCID: 0000-0002-4365-7569 \\ Uniwersytet Wrocławski \\ Instytut Prawa Cywilnego \\ Zakład Prawa Gospodarczego i Handlowego
}

\title{
ZAŁOŻENIE O RACJONALNOŚCI PRAWODAWCY W PROCESIE WYKŁADNI W PRAWIE SPÓŁEK
}

\begin{abstract}
Abstrakt: Założenie o racjonalności prawodawcy pełni w obszarze wykładni prawa istotną funkcję, szczególnie w dobie ,inflacji przepisów” (będącej zaprzeczeniem istotnej dla obrotu gospodarczego stałości), nie najlepszej legislacji, często pozbawionej spojrzenia systemowego, i wobec złożoności elementów stosunków prawnych oraz faktycznych w obszarze spółek z jednej strony, a z drugiej strony zadań, które przynależą do regulacji prawa spółek dla bezpieczeństwa obrotu i jego uczestników oraz wspierania inwestycji. Założenie o racjonalności prawodawcy (oraz elementy treściowe na to założenie się składające) jako wytwór nauki prawa powinno dać podmiotom stosującym prawo (a zatem praktykom) narzędzie do stosowania przepisów w sposób właściwy i dostosowany do uwarunkowań danego stanu faktycznego. Na przykładach wybranych orzeczeń jest widoczne, że sądy, sięgając po to założenie, często skupiają się tylko na jakimś jednym jego aspekcie lub opierają się na samym pojęciu racjonalności. Stosowanie założenia o racjonalności prawodawcy nie powinno jednak prowadzić do sytuacji, w których podmiot stosujący prawo zamiast dostarczyć uzasadnienia przyjętej w rezultacie wykładni oceny prawnej blankietowo odwołuje się do tego założenia, nie podejmując żadnego wysiłku opisania, jak poszczególne elementy treściowe na to założenie się składające, powinny w konkretnym przypadku wpływać na rozumienie przepisów, szczególnie jeśli ma ono odbiegać od ich literalnego brzmienia.
\end{abstract}

Słowa kluczowe: założenie racjonalnego ustawodawcy, prawo spółek, wykładnia, stosowanie prawa

\section{WPROWADZENIE}

Koncepcja racjonalnego prawodawcy jest nazywana jednym z największych osiągnięć polskiej teorii prawa ${ }^{1}$. Opiera się ona na nieznajdującym po-

1 Tak A. Borowicz, Argument interpretacyjny odwolujacy się do woli rzeczywistego prawodawcy, „Studia Prawno-Ekonomiczne” 79, 2009, s. 9; por. także P. Kantor-Kozdrowicki, Racjonalność prawodawcy jako paradygmat nauk prawnych, „Folia Iuridica Universitatis Wratislaviensis” 2018, nr 7, s. 95 n. Godzi się odnotować też stanowisko krytyczne wobec tej koncepcji, wywodzące, że przyjęcie założenia o racjonalności ustawodawcy nie jest konieczne do prawidłowej interpretacji 
twierdzenia w rzeczywistości założeniu, że przepisy tworzone są przez jeden, w pełni racjonalny podmiot, „konsekwentnie kierujący się określoną spójną wiedzą i określonymi ocenami, uporządkowanymi preferencyjnie"2. Racjonalność jest też definiowana jako obejmująca kierowanie się logiką, rozumem, prawdą oraz opieraniem się na rzetelnych podstawach ${ }^{3}$. Według postulatów składających się na zasadę racjonalności wiedza prawodawcy jest niesprzeczna i uwzględnia swoje konsekwencje logiczne ${ }^{4}$. Co ważne w interpretacji przepisów — zakłada się przy tym racjonalność językową oraz racjonalność jurydyczną (założenie wyznaczające wiedzę prawniczą) prawodawcy ${ }^{5}$. Traktowanie przez racjonalnego prawodawcę systemu prawa w sposób spójny obejmuje uwzględnianie prawa unijnego jako elementu polskiego systemu prawa zarówno w procesie tworzenia, jak i wykładni prawa krajowego ${ }^{6}$. Element ten jest istotny dla prawa spółek, ponieważ w obszarze prawa unijnego podjętych zostało w ramach Unii Europejskiej wiele działań w celu harmonizacji, szczególnie prawa spółek kapitałowych ${ }^{7}$. Warto także wspomnieć, że zakłada się znajomość przez racjonalnego prawodawcę orzecznictwa organów stosujących prawo oraz literatury prawniczej w regulowanym przez prawodawcę obszarze, a w przypadku ugruntowanych w orzecznictwie oraz literaturze stanowisk ustawodawca z tymi stanowiskami się liczyć ${ }^{8}$. W procesie wykładni — zgodnej z założeniem o racjonalności prawodawcy — należy uwzględniać cele danego przepisu, aby chronić określone, założone przez prawodawcę, wartości, w tym realizować cele ochronne danej normy względnie dążyć do uniknięcia określonego stanu rzeczy 9 .

prawa - por. L. Morawski, Teoria prawodawcy racjonalnego a postmodernizm, PiP 2000, nr 1, s. 33 n. Jakkolwiek założenie o racjonalności ustawodawcy odnoszone jest zarówno do procesu tworzenia prawa, jak i wykładni prawa (por. zamiast wielu M. Sala-Szczypiński, Racjonalność prawodawcy a odpowiedzialność za ,, bubel ustawowy”, [w:] Studia prawnicze: rozprawy i materiały, red. T. Biernat, Kraków 2009, s. 28), to w niniejszym opracowaniu akcent położony zostanie przede wszystkim na sferę wykładni przepisów.

2 Tak Z. Ziembiński, Problemy podstawowe prawoznawstwa, Warszawa 1980, s. 19.

3 Por. M.A. Liwo, Nieracjonalność działań prawodawcy jako jedna z przyczyn niepoprawności prawa - wybrane przykłady z prawa administracyjnego, karnego i prawa pracy, „Przegląd Prawa Publicznego" 2019, nr 6, s. 9.

4 Tak L. Nowak, Interpretacja prawnicza. Studium z metodologii prawoznawstwa, Warszawa 1973, s. 39 n.

5 Por. S. Wronkowska, Prawodawca racjonalny jako wzór dla prawodawcy faktycznego, [w:] Szkice z teorii prawa i szczegółowych nauk prawnych, red. S. Wronkowska, M. Zieliński, Poznań 1990, s. 188 n.

6 Por. M. Zieliński, Wykładnia prawa. Zasady - reguły - wskazówki, Warszawa 2017, s. $262-263$.

7 Por., przykładowo, dyrektywa Parlamentu Europejskiego i Rady (UE) 2017/1132 z dnia 14 czerwca 2017 roku w sprawie niektórych aspektów prawa spółek (OJ L 169, 30.6.2017, s. 46127).

8 Tak M. Zieliński, op. cit., s. 262-263.

9 Ibidem, s. 266-267. 
Prawodawca racjonalny jest zwykle przeciwstawiany faktycznemu (rzeczywistemu) prawodawcy, rozumianemu jako organ państwa wyposażony w kompetencje do stanowienia przepisów prawa lub jako poszczególni ludzie, biorący udział w procesie przygotowywania i stanowienia aktów prawnych ${ }^{10}$. Dziś w doktrynie często podnosi się, że jakość stanowienia prawa ciągle spada, ,inflacja prawa" zmniejsza przejrzystość systemu prawnego i przewidywalność uregulowań prawnych ${ }^{11}$. Ustawodawca faktyczny oddala się zatem coraz bardziej od ustawodawcy racjonalnego. Mimo to wydaje się, że nie powinno się w procesie wykładni prawa całkowicie pomijać roli materiałów legislacyjnych, na których przy tworzeniu przepisów opierał faktyczny ustawodawca. Efekty działań ustawodawcy faktycznego powinny być raczej punktem wyjścia do stosowania założenia racjonalności ustawodawcy. Za trafną należy uznać ocenę wyrażoną w orzecznictwie, że ustawodawca faktyczny nie może — przykładowo przez treść materiałów legislacyjnych — krępować dozwolonej interpretacji dokonywanej przez sąd w jego aktywności orzeczniczej ${ }^{12}$. Odwołanie do racjonalności prawodawcy nie powinno jednak zwalniać interpretatorów z obowiązku rozpoczęcia procesu wykładni od literalnej treści przepisu oraz prowadzić do ignorowania materiałów legislacyjnych, ponieważ inne podejście musiałoby skutkować coraz większą chwiejnością i nieprzewidywalnością rozstrzygnięć ${ }^{13}$. Tymczasem szczególnie w obszarze prawa obrotu gospodarczego istotną wartością jest przewidywalność ocen prawnych określanych stanów faktycznych i pewność prawa, ponieważ wiąże się to w sposób nieunikniony z szacowaniem ryzyka określonych zamierzeń gospodarczych. Dlatego za trafne należy uznać stanowisko, że w procesie wykładni przepisów przydatne jest uwzględnianie intencji faktycznego prawodawcy, dotyczące zakresu zastosowania danej normy prawnej, sposobu rozumienia wyrażeń językowych tworzących daną normę prawną oraz ujawnionego celu (ratio legis) danego uregulowania ${ }^{14}$. Natomiast zbyt daleko idące wydaje się stanowisko ograniczające możliwość odejścia od wykładni językowej wyłącznie do sytuacji, w których prowadziłaby ona do niedorzecznych rezultatów (argumentum ad absurdum ${ }^{15}$.

10 Por. przykładowo A. Bielska-Brodziak, Śladami prawodawcy faktycznego. Materiały legislacyjne jako narzędzie wyktadni prawa, Warszawa 2017, s. 79 n.

11 Por. zamiast wielu M.A. Liwo, op. cit., s. 12.

12 Tak trafnie uchwała Sądu Najwyższego z dnia 17 stycznia 2000 roku, III CZP 49/00, OSNC 2001/4/53.

13 Por. przykładowo A. Bielska-Brodziak, op. cit., s. 85; A. Borowicz, op. cit., s. 19. Interpretacja nie może przy tym opierać się na dowolności.

14 Por. A. Borowicz, op. cit., s. 20.

15 Tak tymczasem H. Filipczyk, Opodatkowanie majątku otrzymanego przez akcjonariusza spótki komandytowo-akcyjnej w wyniku likwidacji spółki a dopuszczalność odstęsstwa od wykładni językowej, „Monitor Podatkowy” 2015, nr 5, s. 15. 


\section{O POTRZEBIE POSŁUGIWANIA SIE ZAŁOŻENIEM O RACJONALNOŚCI PRAWODAWCY PRZY WYKŁADNI PRAWA SPÓŁEK}

W obszarze prawa spółek korzystanie w procesie wykładni z założenia o racjonalności prawodawcy powinno mieć istotne znaczenie.

Przede wszystkim należy wskazać na pewnego rodzaju niedostatki natury normatywnej w tym obszarze, które wykładnia może pozwolić wyeliminować lub przynajmniej złagodzić. Otóż, odmiennie niż pod rządami kodeksu handlowego ${ }^{16}$, prawo handlowe (którego część prawo spółek stanowi) nie doczekało się swojej części ogólnej ${ }^{17}$. Chociaż prawo handlowe (w tym prawo spółek) jest częścią prawa cywilnego, to jednak cechuje się pewną specyfiką ze względu na przedmiot oraz stosowane konstrukcje. W obrocie gospodarczym występuje bowiem konieczność uwzględniania profesjonalnego charakteru jego uczestników (przedsiębiorców), co z kolei skutkować powinno pozostawieniem im w obszarze stosunków dwustronnie profesjonalnych większej swobody działania, ale jednocześnie wymaga formalizowania elementów wpływających na poziom bezpieczeństwa obrotu, jak przykładowo zasad reprezentacji. Dodatkowo w obszarze prawa handlowego (w tym w szczególności prawa spółek) mamy do czynienia ze swoistymi konstrukcjami prawnymi ${ }^{18}$. Tymczasem polski ustawodawca dokonał jedynie tak zwanej komercjalizacji przepisów kodeksu cywilnego, punktowo, a nie systemowo, dodając tylko poszczególne postanowienia typowe dla obrotu gospodarczego, sankcjonując w Polsce tak zwany system monistyczny ${ }^{19}$.

Kolejnym argumentem świadczącym o potrzebie stosowania założenia o racjonalności prawodawcy przy wykładni przepisów z zakresu prawa spółek jest zawarte

16 Rozporządzenie Prezydenta z mocą ustawy z dnia 27 czerwca 1934 roku, Dz.U. Nr 57, poz. 502.

$17 \mathrm{Z}$ momentem wejścia w życie kodeksu cywilnego kodeks handlowy został uchylony, a utrzymano okresowo w mocy niektóre tylko jego przepisy, por. art. VI $\S 1$ ustawy z dnia 23 kwietnia 1964 roku (Dz.U. Nr 16, poz. 94) - przepisy wprowadzające kodeks cywilny. Polski ustawodawca stanął bowiem na stanowisku zasady jedności prawa cywilnego, nie tworząc nawet częściowej kodyfikacji przepisów prawa handlowego i gospodarczego; por więcej S. Włodyka, Prawo gospodarcze. Zarys systemu. Część ogólna, t. 1, Warszawa 1981, s. 18; oraz Z. Radwański, Zagadnienie inkorporacji do kodeksu cywilnego prawa rodzinnego i gospodarczego, RPEiS 1961, z. 4, s. 1-19.

18 Por. przykładowo w zakresie rozważań na temat czynności wewnątrzkorporacyjnych J. Frąckowiak, Uchwała zgromadzenia wspólników spótki kapitałowej jako czynność prawna wewnątrzkorporacyjna, PPH 2018, nr 9, s. $22 \mathrm{n}$.

19 Na temat reformy prawa cywilnego po 1989 roku por. A. Wolter, J. Ignatowicz, K. Stefaniuk, Prawo cywilne. Zarys części ogólnej, Warszawa 2018, s. 63 n.; S. Włodyka, [w:] Prawo handlowe - część ogólna, red. S. Włodyka, Warszawa 2009, s. 6 n.; oraz J. Frąckowiak, O konieczności dalszych zmian prawa cywilnego, $w$ szczególności w odniesieniu do podmiotów umów w obrocie gospodarczym, PPH 1999, nr 3, s. 7 n. 
w samym kodeksie spółek handlowych ${ }^{20}$ odesłanie. Zakres przedmiotowy ustawy - Kodeks spółek handlowych został bowiem ograniczony do obszaru tworzenia, organizacji, funkcjonowania, rozwiązywania, łączenia, podziału i przekształcania spółek handlowych (art. 1 § 1 k.s.h.). Jednocześnie, zgodnie z art. 2 k.s.h., w sprawach objętych zakresem przedmiotowym regulacji tego kodeksu należy co do zasady stosować wprost przepisy kodeksu cywilnego. Jeżeli jednak wymagać tego będzie „właściwość (natura) stosunku prawnego spółki handlowej”, przepisy kodeksu cywilnego winny być już stosowane jedynie odpowiednio ${ }^{21}$. Regulacja ta - już według założenia przyjętego przez samego ustawodawcę faktycznego — nie ma zatem charakteru zupełnego. Dla podmiotu stosującego prawo odesłanie to stwarza konieczność dokonania oceny w każdym indywidualnym przypadku wymagającym zastosowania do spółek przepisów zawartych w kodeksie cywilnym, po pierwsze, czy dana sprawa jest już uregulowana w kodeksie spółek handlowych. W razie zaś udzielenia oceny negatywnej na tak postawione pytanie interpretator musi - po drugie - stwierdzić, czy właściwy przepis kodeksu cywilnego może zastosować wprost, czy też stosowaniu przepisu wprost w konkretnym przypadku sprzeciwiałaby się właściwość (natura) stosunku spółki. Zgodnie z rozumieniem „odpowiedniości” względy wynikające z właściwości stosunku spółki mogą prowadzić do całkowitego wyłączenia stosowania danego przepisu kodeksu cywilnego lub stosowania go w postaci zmodyfikowanej. Co zrozumiałe, przepisy kodeksu spółek handlowych nie zawierają definicji legalnej pojęcia „właściwości (natury) stosunku spółki”, bo pojęcie to wymyka się definicjom przy wykorzystaniu prawnego instrumentarium ${ }^{22}$. W takiej sytuacji to właśnie odwołanie do założenia o racjonalności prawodawcy, wraz z wypracowanymi przez doktrynę jego składnikami treściowymi (instrumentarium), powinny ułatwiać podmiotowi stosującemu prawo budowanie uzasadnienia rezultatu wykładni przepisu. W tym znaczeniu założenie to powinno pełnić funkcję wspierającą prawidłowe stosowanie przepisów prawa spółek, zgodnie z potrzebami obrotu gospodarczego. Rolą interpretatora powinno być jednak objaśnienie, jak na gruncie konkretnego stanu faktycznego, przez zastosowanie założenia o racjonalności ustawodawcy, dokonuje on określonych wnioskowań i wyborów.

Stosowanie założenia o racjonalności prawodawcy w prawie spółek uzasadnia ponadto złożoność stosunków prawnych typowych dla tej dziedziny prawa. Otóż standardowo w spółkach można rozróżniać różne interesy, niejednokrotnie pozostające z sobą w otwartym lub potencjalnym konflikcie. $\mathrm{Na}$ przykładzie spółki akcyjnej można wskazać następujące grupy interesów: interes samej spółki akcyjnej, interesy poszczególnych akcjonariuszy (też czę-

20 Ustawa z dnia 15 września 2000 roku - Kodeks spółek handlowych (Dz.U. Nr 94, poz. 1037 ze zm.), dalej: k.s.h.

${ }^{21}$ Por. więcej zamiast wielu S. Sołtysiński, [w:] S. Sołtysiński et al., Kodeks spółek handlowych. Komentarz do artykutów 1-150, t. 1, Warszawa 2006, s. 40 n.

22 Warto wspomnieć, że także pojęcie właściwości (natury) stosunku zawarte w art. $353^{1}$ k.c., a wyznaczające granice swobody umów, nie ma swojej definicji legalnej. 
sto zróżnicowane, jak choćby według niezupełnego podziału na akcjonariuszy większościowych i mniejszościowych), interesy wierzycieli spółki (też tworzących niejednorodną grupę, a obejmującą także pracowników spółki), interesy poszczególnych organów spółki (zarządu, rady nadzorczej) i ich poszczególnych członków (piastunów). Do tego dochodzą jeszcze relacje z obszaru prawa koncernowego i oddziaływanie przez spółkę dominującą na zarząd jej spółki zależnej. W rezultacie w procesie stosowania przepisów prawa należy uwzględniać tego rodzaju uwarunkowania. Faktyczny prawodawca zaś ma często trudności, aby opisaną złożoność odpowiednio uchwycić i uregulować w sposób należycie wyważony.

Założenie o racjonalności prawodawcy w procesie wykładni przepisów powinno też pomagać w budowaniu pozytywnego obrazu polskiego prawa spółek, co również jest istotne z punktu widzenia pobudzania przedsiębiorczości wewnątrzkrajowej, jak również przyciągania kapitału zagranicznego. Przedsiębiorczość, a także inwestycje zagraniczne, mają bowiem istotne znaczenie dla wielkości produktu krajowego i rozwoju gospodarczego Polski. Wielokrotnie zaś — przede wszystkim w odniesieniu do inwestycji zagranicznych — podkreśla się swoistą konkurencję prawodawstw w rywalizacji o inwestycje. W wypadku prawa spółek mamy przy tym do czynienia zarówno $\mathrm{z}$ inwestycjami w postaci zakładania nowych podmiotów, jak i inwestycjami polegającymi na nabywaniu instrumentów finansowych, emitowanych przez przedsiębiorców (jak akcje czy obligacje) lub innych tytułów uczestnictwa w spółkach. Proces inwestowania czy też podjęcie decyzji o rozpoczęciu działalności gospodarczej w formie spółki wymaga zaś podjęcia określonej decyzji, której jednym z wyznaczników może być właśnie ocena otoczenia prawnego i oferowanych przez ustawodawcę ,narzędzi” normatywnych do prowadzenia działalności gospodarczej oraz poziomu bezpieczeństwa i pewności prawa. Wyzwanie to powiększa dodatkowo postępujący rozwój nowych technologii, w tym środków komunikowania się, który w naturalny sposób wchodzi do obszaru spółek, na co reaguje również ustawodawca, ale co w nieuchronny sposób stwarza nowe stany faktyczne, wymagające oceny prawnej. Stosowanie założenia o racjonalności prawodawcy powinno wzmacniać przy tym bezpieczeństwo obrotu oraz pewność prawa, tak pożądanych dla obrotu gospodarczego i jego uczestników.

Należy jednak wspomnieć, że zadania interpretatorom nie ułatwia sam prawodawca faktyczny, który w obszarze prawa spółek nie zawsze stosuje założenia o racjonalności prawodawcy przypisane do procesu tworzenia prawa. Otóż często brakuje spojrzenia systemowego w kwestii wprowadzanych zmian. Jak pokazuje chociażby przykład prostej spółki akcyjnej (PSA), wiele zawartych w niej uregulowań (abstrahując od ich oceny) prowadzi do niespójności systemowych i dalece wykracza poza uzasadnienie odrębności typologicznej tej spółki ${ }^{23}$. Ustawodawca

23 Por. przykładowo M. Podleś, L. Siwik, Likwidacja spótek z perspektywy projektowanej regulacji prostej spótki akcyjnej, PPH 2018, nr 9, s. 43 n. 
też nie zawsze przy tworzeniu przepisów uwzględnia aktualny dorobek orzeczniczy i doktryny ${ }^{24}$.

\section{WYBRANE PRZYKŁADY ZASTOSOWANIA ZAŁOŻENIA O RACJONALNOŚCI PRAWODAWCY}

Przeglądając orzecznictwo sądowe w obszarze prawa handlowego, w tym dotyczące spółek, można odnaleźć przykłady odwoływania się sądów w uzasadnieniach ich rozstrzygnięć i w ramach prowadzonego wywodu prawnego do założenia o racjonalności ustawodawcy bądź też do samego, a zwykle bliżej niedefiniowanego (a zatem jak można przypuszczać, opartego na definicji leksykalnej), pojęcia „racjonalności”.

Zastosowanie założenia o racjonalnym prawodawcy posłużyło przykładowo Sądowi Najwyższemu w wyroku z dnia 12 lutego 2009 roku $^{25}$ do oceny dopuszczalności wskazania sukcesora przez organ założycielski w toku likwidacji samodzielnego publicznego zakładu opieki zdrowotnej, prowadzonego $\mathrm{w}$ formie spółki z ograniczoną odpowiedzialnością. Otóż założenie to posłużyło do uzasadnienia trafnego aksjologicznie wniosku, że organ założycielski zakładu opieki zdrowotnej nie może w sposób dowolny wskazać podmiotu, który przejąłby zobowiązania likwidowanego zakładu, ponieważ inny wniosek mógłby prowadzić do naruszenia interesów wierzycieli takiego zakładu. $\mathrm{Z}$ kolei w postanowieniu Sądu Najwyższego z dnia 1 sierpnia 2002 roku $^{26}$ odwołanie do założenia racjonalnego ustawodawcy pozwoliło składowi orzekającemu na uzasadnienie, że argumenty skarżącego, odrywające się od literalnej treści odpowiedniego przepisu, nie są trafne. Sąd przyjął bowiem, że gdyby „racjonalnie działający ustawodawca" chciał ograniczyć zaskarżalność określonego rodzaju orzeczeń, to dałby temu wyraz w treści przepisu, a jednocześnie nie zachodzi sytuacja, w której literalna wykładnia prowadziłaby do wyników, „niedających się pogodzić z racjonalnym działaniem ustawodawcy". Kolejny przykład zastosowania założenia o racjonalności ustawodawcy - poza obszarem prawa spółek, ale odnoszący się do kwestii podmiotowości - to wyrok Sądu Apelacyjnego w Poznaniu z 14 lutego 2008 roku $^{27}$. W orzeczeniu tym przyjęto, że powód (działający w formie prawnej Okręgowej Izby Inżynierów Budownictwa) zachował na czas trwania procesu osobo-

${ }^{24}$ Wskazana już forma prostej spółki akcyjnej może służyć jako dobry przykład wprowadzenia nowego typu spółki do polskiego systemu podmiotów, mimo wielu sprzeciwiających się temu głosów i krytycznych opinii doktryny prawa handlowego, por. J. Janeta, J. Ulański, Sprawozdanie z konferencji VII Forum Prawa Spótek 18.05.2018 r. — „Reforma Kodeksu spółek handlowych — systemowa zmiana czy autorskie projekty”, PPH 2018, nr 9, s. 4 n.

25 Sygn. akt V CSK 267/08, niepubl.

26 Sygn. akt II CZ 70/02, niepubl.

27 Sygn. akt. I ACa 49/08, niepubl. 
wość prawną, ponieważ założenie racjonalnego ustawodawcy nakazuje w świetle art. 35 k.c. przyjąć, że, ,jeżeli wprowadza on w drodze ustawy nową kategorię osób prawnych, to jednocześnie w tej samej ustawie określa podstawy i sposób likwidacji tych podmiotów". W efekcie sąd ten z zawartego w art. 10 ust. 2 ustawy o samorządach zawodowych architektów, inżynierów budownictwa i urbanistów ${ }^{28}$ uprawnienia krajowej izby samorządu do ustalania obszarów i siedzib działania okręgowych izb wywiódł również jej prawo do znoszenia (likwidacji) izb.

Z kolei przykład zastosowania samej przesłanki „racjonalności” zawarty jest w wyroku Sądu Apelacyjnego w Warszawie z dnia 19 grudnia 2006 roku $^{29}$. Sąd ten, oceniając różne tryby przekształceń z udziałem spółki cywilnej i odnoszącą się do niej kwestię następstwa prawnego, przyjął, że „nie ma racjonalnego uzasadnienia negowanie sukcesji uniwersalnej w płaszczyźnie prawa materialnego dla spółek podlegających przerejestrowaniu" w jednym z trybów, odnośnie do którego ustawodawca nie przewidział regulacji dotyczącej kwestii przejścia praw i obowiązków przekształcanej spółki (wspólników takiej spółki). Sąd ten trafnie rozwinął założenie racjonalności, przyjmując że odrzucenie tej koncepcji prowadziłoby do wniosku, iż powstała z przekształcenia spółki cywilnej spółka jawna nie miałaby żadnego majątku.

Warto podkreślić, że w doktrynie trafnie zwraca się uwagę na pewne zagrożenie związane z posługiwaniem się założeniem o racjonalności prawodawcy, wskazując, że w praktyce stosowania prawa może ono prowadzić do zastępowania merytorycznej argumentacji na rzecz określonego sposobu wykładni tekstu aktu prawnego, przez co brakuje wskazania własnych podglądów podmiotu stosującego prawo oraz stanowiska faktycznego prawodawcy ${ }^{30}$. Tymczasem posługiwanie się w procesie wykładni założeniem o racjonalności prawodawcy i w efekcie odejście od literalnego brzmienia przepisów tym staranniej powinno zostać uzasadnione przez podmiot stosujący prawo, który właśnie powinien wskazać, dlaczego w konkretnym stanie faktycznym oparcie się wyłącznie na literalnym brzmieniu przepisu i tak wyrażonej woli faktycznego ustawodawcy nie może się ostać. Należy podkreślić, że w świetle obowiązujących przepisów koniecznym elementem składowym uzasadnienia orzeczenia sądu w sprawie cywilnej jest „wyjaśnienie podstawy prawnej wyroku z przytoczeniem przepisów prawa" (art. $327^{1} \S 1$ k.p.c.). Z kolei to dopiero uzasadnienie orzeczenia pozwala zwykle na dokonanie oceny jego prawidłowości w toku kontroli instancyjnej lub też może stać się wartościowym materiałem pomocniczym dla innych podmiotów stosujących prawo w zbliżonych stanach faktycznych.

\footnotetext{
28 Ustawa z dnia 15 grudnia 2000 roku, tekst jedn. Dz.U. z 2019 r. poz. 1117.

29 Sygn. akt I ACa 748/06, niepubl.

30 Tak A. Borowicz, op. cit., s. 16.
} 


\section{PODSUMOWANIE}

Założenie o racjonalności prawodawcy pełni w obszarze prawa spółek przy wykładni ważną funkcję, szczególnie w dobie „inflacji przepisów” (będącej zaprzeczeniem istotnej w obrocie gospodarczym stałości), nie najlepszej legislacji, często pozbawionej spojrzenia systemowego i wobec złożoności elementów stosunków prawnych oraz faktycznych w obszarze spółek z jednej strony, a z drugiej strony zadań, które do spełnienia ma regulacja prawa spółek dla bezpieczeństwa obrotu i jego uczestników oraz wspierania inwestycji. Założenie o racjonalności prawodawcy (oraz elementy treściowe na to założenie się składające) jako wytwór nauki prawa powinno dać podmiotom stosującym prawo (a zatem praktykom) narzędzie do używania przepisów w sposób dostosowany do uwarunkowań danego stanu faktycznego. Na przykładach wybranych orzeczeń jest widoczne, że sądy, sięgając po to założenie, często skupiają się tylko na jakimś jednym jego aspekcie lub nawet opierają się wyłacznie na samym pojęciu racjonalności. Stosowanie założenia o racjonalności prawodawcy nie powinno prowadzić do sytuacji, w których podmiot stosujący prawo zamiast dostarczyć uzasadnienie przyjętej w rezultacie wykładni oceny prawnej, blankietowo odwołuje się do tego założenia, nie podejmując żadnego wysiłku opisania, jak poszczególne elementy treściowe na to założenie się składające powinny w konkretnym przypadku wpływać na rozumienie przepisów, szczególnie jeśli ma ono odbiegać od ich literalnego brzmienia.

\section{NOTION OF THE LAW-MAKER'S RATIONALITY IN THE FIELD OF COMPANY LAW}

\section{Summary}

The notion of law-maker's rationality has to play a paramount fulfilling role in the area of law's interpretation, concerning commercial law in Poland, especially facing a contemporary epoch of 'overdone legal provisions'. The notion of law-maker's rationality (including the textual contents underpinning such a notion) would rather provide the actors who use to apply the law (so: mostly the actors with practical approach) with an 'appliance' for their realization of legal provisions in a proper and most fact-conform way considering any sets of factual circumstances in concrete cases. Choosing of court rulings as parade examples makes us perceive that the courts - during their reference to such a notion - focus on the only one aspect of that notion or they just rely generally on the notion of rationality (as a whole). The model application of the notion of law-maker's rationality would rather not lead to any situation where the actor who uses to apply the law could make reference to such a notion in a blank way instead of providing the justification speaking for their legal opinion (interpretative output). The actor (-s) is (are) not open to resign from any effort to might be in a position to describe on how the particular elements (constituting such a notion in textual aspect) do influence the applicable understanding of said legal provisions in their concrete case.

Keywords: notion of the law-maker's rationality, company law construing (of legal wordings) applicability of law 


\section{BIBLIOGRAFIA}

Bielska-Brodziak A., Śladami prawodawcy faktycznego. Materiały legislacyjne jako narzędzie wykładni prawa, Warszawa 2017.

Borowicz A., Argument interpretacyjny odwołujący się do woli rzeczywistego prawodawcy, „Studia Prawno-Ekonomiczne" 79, 2009.

Filipczyk H., Opodatkowanie majątku otrzymanego przez akcjonariusza spótki komandytowo-akcyjnej w wyniku likwidacji spótki a dopuszczalność odstępstwa od wyktadni językowej, „Monitor Podatkowy" 2015, nr 5.

Frąckowiak J., O konieczności dalszych zmian prawa cywilnego, w szczególności $w$ odniesieniu do podmiotów umów w obrocie gospodarczym, PPH 1999, nr 3.

Frąckowiak J., Uchwała zgromadzenia wspólników spółki kapitałowej jako czynność prawna wewnatrzkorporacyjna, PPH 2018, nr 9.

Janeta J., Ulański J., Sprawozdanie z konferencji VII Forum Prawa Spótek 18.05.2018 r. — „, Reforma Kodeksu spótek handlowych — systemowa zmiana czy autorskie projekty”, PPH 2018, nr 9.

Kantor-Kozdrowicki P., Racjonalność prawodawcy jako paradygmat nauk prawnych, „,Folia Iuridica Universitatis Wratislaviensis" 2018, nr 7.

Liwo M.A., Nieracjonalność działań prawodawcy jako jedna z przyczyn niepoprawności prawa - wybrane przykłady z prawa administracyjnego, karnego i prawa pracy, „Przegląd Prawa Publicznego" 2019, nr 6.

Morawski L., Teoria prawodawcy racjonalnego a postmodernizm, PiP 2000, nr 1.

Nowak L., Interpretacja prawnicza. Studium z metodologii prawoznawstwa, Warszawa 1973.

Podleś M., Siwik L., Likwidacja spółek z perspektywy projektowanej regulacji prostej spótki akcyjnej, PPH 2018, nr 9.

Radwański Z., Zagadnienie inkorporacji do kodeksu cywilnego prawa rodzinnego i gospodarczego, RPEiS 1961, z. 4.

Sala-Szczypiński M., Racjonalność prawodawcy a odpowiedzialność za „,bubel ustawowy”, [w:] Studia prawnicze: rozprawy i materiały, red. T. Biernat, Kraków 2009.

Sołtysiński S., [w:] S. Sołtysiński, A. Szajkowski, A. Szumański, J. Szwaja, M. Tarska, Kodeks spółek handlowych. Komentarz do artykułów 1-150, t. 1, Warszawa 2006.

Włodyka S., [w:] Prawo handlowe - część ogólna, red. S. Włodyka, Warszawa 2009.

Włodyka S., Prawo gospodarcze. Zarys systemu. Część ogólna, t. 1, Warszawa 1981.

Wolter A., Ignatowicz J., Stefaniuk K., Prawo cywilne. Zarys części ogólnej, Warszawa 2018.

Wronkowska S., Prawodawca racjonalny jako wzór dla prawodawcy faktycznego [w:] Szkice z teorii prawa i szczegółowych nauk prawnych, red. S. Wronkowska, M. Zieliński, Poznań 1990.

Zieliński M., Wykładnia prawa. Zasady — reguly — wskazówki, Warszawa 2017.

Ziembiński Z., Problemy podstawowe prawoznawstwa, Warszawa 1980. 